\title{
"Pola Rekrutmen Anggota dalam Mengembangkan Baitul Maal Wa Tamwil Sanama Cileunyi Bandung"
}

\author{
(Studi Deskriptif di BMT Sanama J1 Raya Percobaan No 7
}

Cileunyi Bandung)

\author{
Muhammad Hudan Amirulloh ${ }^{1 *}$ \\ ${ }^{1}$ Jurusan Manajemen Dakwah, Fakultas Dakwah dan Komunikasi, Universitas Islam Negeri \\ Sunan Gunung Djati Bandung \\ *Email : Mubammad.hudan@student.uinsgd.ac.id
}

\begin{abstract}
ABSTRAK
Krisis ekonomi yang melanda bangsa Indonesia sekarang ini, telah menggugah banyak pihak untuk memikirkan bagaimana mengembangkan usaha menengah kecil sebagai fundamen ekonomi Indonesia mendatang. Bangsa Indonesia yang merupakan kaum mayoritas Islam dituntut untuk berpartisipasi. Kemudian pada tahun 1992 berdirilah Bank Muammalat Indonesia sebagai bukti awal dari kepedulian umat Islam terhadap ekonomi Indonesia. Seiring bergulirnya waktu berdirilah Lembaga Keuangan yang berbasiskan Syari'at, salah satunya yaitu BMT. BMT sebagai Lembaga Ekonomi Syari'ah mempunyai amanah untuk mengembangkan ekonomi Islam, salah satunya dengan cara pengelolaan dan pemanfaatan SDM yang ada, dengan melaksanakan perekrutan sejumlah anggota sebagai staff yang berkualitas dengan tujuan untuk menghasilkan sejumlah anggota yang sesuai dengan apa yang diharapkan. Karena perekrutan anggota yang berkualitas sangat berpengaruh terhadap perkembangan BMT itu sendiri. Dengan demikian ekonomi Islam akan ikut berkembang dan maju. Penelitian ini bertujuan untuk mengetahui rekrutmen, fungsi rekrutmen, dan pola rekrutmen yang dilakukan di BMT Sanama Cileunyi Bandung, juga untuk mengetahui upaya penghimpunan dan penyaluran dana sekaligus upaya sosialisasi produk di BMT Sanama Cileunyi Bandung kepada masyarakat. Penelitian ini menggunakan metode deskriptif yang akan menggambarkan bagaimana rekrutmen, fungsi rekrutmen, pola rekrutmen, dan hasil daripada rekrutmen anggota di BMT Sanama Cileunyi Bandung. Sedangkan untuk teknik pengumpulan data, penulis melakukan
\end{abstract}


teknik wawancara dengan staff dan pengurus BMT Sanama Cileunyi Bandung, teknik observasi, dan studi dokumentasi. Data yang ditemukan menunjukan bahwa fungsi rekrutmen menurut BMT Sanama yaitu: (1) Untuk memikat para pelamar (2) Untuk menyaring calon pelamar (3) Untuk menambah staff (pegawai) bagi BMT Sanama (4) Untuk memperluas jaringan kerja BMT Sanama (5) Agar bisa menambah jenis produk BMT Sanama (6) Agar lebih mudah mensosialisasikan segala jenis produknya. Sedangkan pola rekrutmen anggota yang dilakukan di BMT Sanama dilakukan dengan pola tertutup, dimana hanya pelamarpelamar yang memenuhi kualifikasi perusahaan lah yang dapat melamar ke BMT Sanama. Adapun hasil yang dicapai dari pola rekrutmen yang diterapkan di BMT Sanama sangatlah berpengaruh terhadap perkembangan BMT, karena BMT Sanama menggunakan pola rekrutmen tertutup sehingga pelamar kerja yang masuk pun akan sesuai dengan yang diinginkan oleh BMT Sanama.

Kata Kunci : Pola, rekrutmen, pengembangan, Baitul Maal Wa Tamwil (BMT)

\begin{abstract}
ABSTRAK
The current economic crisis hitting the Indonesian nation has inspired many parties to think about how to develop small and medium enterprises as the foundation of Indonesia's future economy. The Indonesian nation, which is the majority of Muslims, is required to participate. Then in 1992 Bank. Muammalat Indonesia was established as early evidence of the concern of Muslims for the Indonesian economy. As time went on, Syari'at-based financial institutions were established, one of which was BMT. BMT as a Shari' ah Economic Institution has the mandate to develop an Islamic economy, one of which is by managing and utilizing existing human resources, by recruiting a number of members as qualified staff with the aim of producing a number of members who are in accordance with what is expected. Because the recruitment of qualified members is very influential on the development of BMT itself. Thus the Islamic economy will also develop and advance. This study aims to determine recruitment, recruitment functions, and recruitment patterns carried out at BMT Sanama Cileunyi Bandung, as well as to determine efforts to raise and distribute funds as well as efforts to socialize products at BMT Sanama Cileunyi Bandung to the public. This study uses a descriptive method that will describe how the recruitment, recruitment function, recruitment patterns, and results of member recruitment at BMT Sanama Cileunyi Bandung. As for data collection techniques, the authors conducted interview techniques with staff and administrators of BMT Sanama Cileunyi Bandung, observation techniques, and study documentation. The data found shows that the recruitment function according to BMT Sanama is: (1) To attract applicants (2) To screen potential applicants (3) To add staff (employees) to BMT Sanama (4) To expand the work network of BMT Sanama (5) In order to add more types of BMT Sanama products (6) In order to make
\end{abstract}


it easier to socialize all types of products. Meanwhile, the member recruitment pattern at BMT Sanama is carried out with a closed pattern, where only applicants who meet the company's qualifications can apply to BMT Sanama. The results achieved from the recruitment pattern implemented at BMT Sanama greatly influence the development of BMT, because BMT Sanama uses a closed recruitment pattern so that the incoming job applicants will match what BMT Sanama wants.

Keywords: Pattern, recruitment, development, Baitul Maal Wa Tamwil (BMT)

\section{PENDAHULUAN}

Baitul Maal Wa Tamwil sebagai salah satu lembaga yang bergerak di bidang ekonomi, memiliki nilai yang signifikan dalam pengembangan ekonomi umat. Ditinjau dari sistem operasional manajemen secara keseluruhan dinilai cukup baik, ini bisa dilihat dari hasil-hasil kegiatan yang dilaksanakan pada bank tersebut, yang mampu melaksanakan program-program yang telah direncanakan. Kesadaran masyarakat untuk membangun sistem ekonomi yang berbasis syari'ah sudah mulai tumbuh dan berkembang, masyarakat dituntut untuk berpartisipasi aktif dalam membangun sistem ekonomi syari'ah dengan memberikan kontribusi positif, bergerak dan melangkah bersama yang lain serta menjadi garda terdepan dan menjadi pilar utama dalam proses pembangunan bangsa ini. Kontribusi tersebut dapat disalurkan melalui lembaga-lembaga Islam, baik lembaga dakwah maupun lembaga ekonomi Islam.

Baitul Maal Wa Tamwil (BMT) sebagai lembaga ekonomi syari'ah, mempunyai amanah untuk mengembangkan ekonomi Islam, salah satunya dengan cara pengelolaan dan pemanfaatan SDM yang ada, dengan melaksanakan perekrutan sejumlah anggota sebagai staff yang berkualitas dengan tujuan untuk menghasilkan sejumlah anggota atau pegawai yang sesuai dengan apa yang diharapkan.

Hasibuan (2001: 174) mengemukakan bahwa rekrutmen atau penarikan adalah "kegiatan mencari dan mempengaruhi tenaga kerja agar mau melamar lowongan pekerjaan yang masih kosong di perusahaan". Sistem perekrutan SDM menjadi sesuatu yang sangat penting karena pada fase inilah seleksi awal atas kinerja pegawai dilakukan apalagi pada dasarnya BMT sebaiknya menerapkan sistem jemput bola dalam mengembangkan usahanya karena BMT merupakan saingan dari lembaga perbankan lainnya, sehingga SDM yang dimiliki oleh BMT pun harus mampu mengoptimalkan ide serta kinerja untuk mencapai target yang diharapkan.

Untuk mencapai target yang diharapkan, maka dalam pengelolaan BMT ini menerapkan kaidah-kaidah keorganisasian. Yaitu terdapatnya sejumlah tenaga 
manusia pengelola organisasi. Disamping ketersediaan SDM juga dikembangkan struktur kerja untuk mengkoordinasikan potensi-potensi SDM tersebut sehingga menjadi sebuah team work yang solid.

Untuk memenuhi kebutuhan SDM guna mengisi jabatan-jabatan yang tersedia di BMT Sanama, perekrutan dilakukan dengan cara prioritas utama mencari dari anggota yang secara skill memiliki kompetensi, bila tidak ada maka anggota diminta mengajukan atau merekomendasikan seseorang yang dianggap capable untuk mengisi jabatan tersebut dan tentunya harus disesuaikan dengan karakteristik organisasi.

Oleh karena itu, sistem perekrutan SDM menjadi sangat penting sebab keberhasilan suatu rencana, baik pencapaian aset dan kepercayaan umat yang telah disusun dengan baik akan sangat bergantung pada pelaksanaanya. Apabila dilaksanakan oleh tenaga kerja yang terampil, disiplin serta berdedikasi tinggi maka akan dapat membuahkan hasil sebagaimana yang diharapkan. Sebaliknya jika pelaksanaan tidak memiliki dan keahlian dalam bidang tugasnya tentulah hasil yang didapatkan akan jauh dari rencana walaupun didukung oleh biaya dan peralatan yang lengkap sekalipun.

Pembentukan suatu ummah di mulai dari pembentukan pribadi - pribadi yang berkualitas, memiliki keyakinan yang kokoh dan akhlak mulia, serta penyerahan diri total kepada Allah. Dengan kata lain pribadi - pribadi pembentuk ummah adalah pribadi - pribadi mutma'innah (Djazuli, 2003 : 400). Pribadi mutma'innah adalah pribadi/jiwa yang telah mendapat ketenangan, telah sanggup untuk menerima cahaya kebenaran sang Ilahi. Juga jiwa yang telah mampu menolak menikmati kemewahan dunia dan tidak bisa dipengaruhi oleh hal tersebut. Pribadi ini membuat pemiliknya merasa berpuas diri dalam pengabdiannya kepada Tuhan. Dia juga akan selalu berbuat amal saleh kebaikan kepada sesama makhluk (Shadily, 1980 : 2325).

Oleh karena itu, jika BMT tidak memperhatikan masalah rekrutmen SDM (tenaga kerja) yang memadai, maka akan berdampak pada eksistensi BMT itu sendiri untuk dapat berkembang dan lebih maju.

\section{LANDASAN TEORITIS}

Pola didalam kamus besar bahasa Indonesia (2001: 884) mengandung arti sebagai berikut:

"Gambar yang dipakai untuk contoh batik, corak batik atau tenun, ragi, sari, potongan kertas yang dipakai sebagai contoh dalam membuat baju dsb, model, system/cara kerja: permainan, pemerintahan, bentuk (struktur) yang 
tetap, kalimat, kombinasi sifat kecenderungan membentuk karangan yang taat asas dan bersifat khas dalam puisi - adaalah bentuk sajak yang dinyatakan dengan bunyi, gerak kata, ataupun arti”.

Jadi pola merupakan bentuk atau model (atau, lebih abstrak, suatu set peraturan) yang bisa dipakai untuk membuat atau untuk menghasilkan sesuatu atau bagian dari sesuatu, khususnya jika sesuatu yang ditimbulkan cukup mempunyai suatu yang sejenis untuk pola dasar yang dapat ditunjukkan atau terlihat, yang mana sesuatu itu dikatakan memamerkan pola.

Pola rekrutmen adalah konstansi berbagai praktek rekrutmen oleh perusahaan atau organisasi. Sungguhpun pada dasarnya setiap organisasi harus berprinsip untuk terbuka bagi kelompok sosial manapun, namun pada level parktis. Kerapkali sulit dihindari bahwa tiap kecenderungan tipe perusahaan menstrukturkan perbedaan dalam menatap konsep rekrutmen yang dianggap ideal bagi perusahaannya (Erawan, et al, 2010: 17).

Pola rekrutmen dibagi menjadi dua cara. Pertama pola rekrutmen terbuka, yakni dengan menyediakan dan memberikan kesempatan yang sama bagi seluruh pelamar untuk ikut bersaing dalam proses penyeleksian. Dasar penilaian dilaksanakan melalui proses dengan syarat-syarat yang telah ditentukan melalui pertimbangan-pertimbangan yang objektif rasional. Dimana setiap pelamar yang memenuhi syarat untuk mengisi jabatan yang telah di sediakan oleh pihak perusahaan. Kedua, pola rekrutmen tertutup yaitu adanya kesempatan bagi para pelamar untuk melamar, akan tetapi dengan kualifikasi dan syarat-syarat yang telah ditentukan oleh pihak perusahaan, sehingga hanya individu-individu yang memenuhi kualifikasi dan syarat-syarat tersebut yang dapat menduduki jabatanjabatan yang tersedia di perusahaan (Tangkilisan: 2003: 188).

Konsep rekrutmen menurut Hasibuan (2001: 174) adalah"kegiatan mencari dan mempengaruhi tenaga kerja agar mau melamar lowongan pekerjaan yang masih kosong di perusahaan". Ia kemudian menambahkan bahwa:

"Yang di maksud dengan"mencari"yaitu menetapkan sumber-sumber tenaga kerja yang akan ditarik dan yang dimaksud dengan"mempengaruhi"yaitu menetapkan cara-cara penarikannya, seperti melalui iklan pada media massa dan atau melalui para karyawan yang ada”.

Tujuan dan maksud dari rekrutmen menurut Harahap (1996: 195) adalah untuk melaksanakan tugas yang sudah ada, menerima wewenang untuk melaksanakannya, bertanggung jawab untuk melaksanakan tugas tersebut, sebagai salah seorang unsur dari organisasi ia ikut bertanggung jawab pada pencapaian 
tujuan organisasi sesuai dengan bidangnya.

Adapun maksud dan tujuan yang lain dari rekrutmen menurut Siagian yang dikutip Gomes (1995: 105) bahwa:

"Maksud rekrutmen adalah untuk mendapatkan persediaan sebanyak mungkin calon-calon pelamar sehingga organisasi akan mempunyai kesempatan yang lebih besar untuk melakukan pilihan terhadap calon pekerja yang dianggap memenuhi standar-standar kualifikasi organisasi”.

Penarikan tenaga kerja (rekrutmen), dimaksudkan utuk memanggil para pelamar untuk mengisi jabatan yang lowong dalam suatu organisasi melalui berbagai sumber tenaga kerja, seperti iklan, kantor penempatan tenaga kerja, lembaga pendidikan, serikat karyawan dan kenalan atau keluarga karyawan.(Manullang, 1988: 199).

"Rekrutmen pada dasarnya merupakan usaha untuk mengisi jabatan/ pekerjaan yang kosong di lingkungan suatu organisasi/ perusahaan. Untuk itu terdapat dua sumber tenaga kerja yakni sumber dari dalam (internal) dan sumber dari luar (eksternal) organisasi/ perusahaan. Dengan kata lain kebijaksanaan rekrutmen sangat tergantung pada fungsi internal dan eksternal pasar tenaga kerja" (Nawawi, 2001: 173).

Disamping itu, sumber rekrutmen menurut Mangkunegara (2001: 34), yaitu ada dua sumber dalam penarikan pegawai, yaitu sumber dari dalam perusahaan yang diupayakan melalui mutasi pegawai yang mencakup promosi jabatan, transfer dan demosi jabatan, kedua sumber dari luar perusahaa yang diupayakan melalui iklan media massa, lembaga pendidikan, dan depnaker.

Kegiatan-kegiatan dalam rekrutmen menurut Nawawi (2001: 170) ada tiga yaitu kegiatan seleksi, kegiatan penempatan, dan kegiatan sosialisasi/orientasi.

Menurut Sulistiyani dan Rosidah (2003: 151) sudut pandang definitive menyatakan yang disebut dengan seleksi adalah serangkaian langkah kegiatan yang dilaksanakan untuk memutuskan apakah seseorang pelamar diterima atau ditolak, dalam suatu instansi tertentu setelah menjalani serangkain tes yang dilaksanakan.

Menurut Siagian (1999: 103) kendala dari rekrutmen diantaranya faktorfaktor organisasional, kebiasaan pencari tenaga kerja, kondisi eksternal.

Kelemahan yang ditimbulkan dari adanya kebijaksanaan promosi dari dalam ialah bahwa para pekerja sedemikian rupa sehingga prestasi kerjanya dipandang memenuhi syarat, kesempatan menaiki tangga karier yang lebih tinggi akan selalu terbuka bagi mereka. dengan perkataan lain, kebijaksanaan"promosi dari dalam"yang diberlakukan dengan sangat konsekuen dapat berakibat terciptanya para pekerja yang berpandangan minimalis.

Setiap organisasi tentunya mempunyai kebijaksanaan tentang upah dan gaji 
yang diberikan kepada karyawannya sebagai ambalan atas waktu, tenaga, keahlian dan keterampilan serta jasa-jasa lainnya yang mereka berikan kepada organisasi.

Yang dimaksud dengan kebijaksanaan tentang status kepegawaian adalah ketentuan tentang apakah para pegawai harus bekerja penuh terhadap organisasi ataukah dimungkinkan bekerja separuh waktu. Jika status kepegawaian adalah paruh waktu, berarti organisasi tidak akan merekrut pegawai separuh waktu dan juga tidak akan membenarkan karyawannya bekerja di tempat lain, meskipun pada waktu senggangnya.

Suatu rencana sumber daya manusia biasanya memberi petunjuk tentang lowongan yang akan diisi melalui rekrutmen tenaga kerja dari luar.

Menurut Djazuli dan Janwari (2002: 183) bahwa yang dimaksud dengan Baitul Maal Wa Tamwil (BMT) adalah"balai usaha mandiri terpadu yang isinya berintikan bayt al-maal wa al-tamwil dengan kegiatan mengembangkan usaha-usaha produktif dan investasi dalam meningkatkan kualitas kegiatan ekonomi pengusaha kecil bawah dan kecil dengan antara lain mendorong kegiatan menabung dan menunjang pembiayaan kegiatan ekonominya".

Menurut Djazuli dan Janwari (2002: 184) BMT memiliki ciri-ciri utama adalah berorientasi bisnis, mencari laba bersama, meningkatkan pemanfaatan ekonomi paling banyak untuk anggota dan lingkungannya, bukan lembaga social tetapi dapat dimanfaatkan untuk mengefektifkan penggunaan zakat, infak, dan sedekah bagi kesejahteraan orang banyak, ditumbuhkan dari bawah berlandaskan peran serta masyarakat di sekitarnya, milik bersama masyarakat kecil bahwa dan kecil dari lingkungan BMT itu sendiri, bukan milik orang seorang atau orang dari luar masyarakat itu.

Jenis-jenis usaha BMT sebenarnya dimodifikasi dari produk perbankan Islam. Oleh karena itu, usaha BMT dapat dibagi kepada dua bagian utama, yaitu membilisasi simpanan dari anggota dan usaha pembiayaan. Bentuk dari usaha memobilisasi simpanan dari anggota dan jamaah itu antara lain berupa Simpanan Mudharabah Biasa, Simpanan Mudharabah Pendidikan, Simpanan Mudharabah Haji, Simpanan Mudharabah Umrah, Simpanan Mudharabah Qurban, Simpanan Mudharabah Idul Fitri, Simpanan Mudharabab Walimah, Simpanan Mudharabah Aqiqah, Simpanan Mudharabab Perumahan, Simpanan Mudharabab Kunjungan Wisata, Titipan Zakat, Infaq, dan Shadaqah (ZIS), Produk simpanan lainnya yang dikembangkan sesuai dengan lingkungan dimana BMT itu berada.

Sedangkan jenis usaha pembiayaan BMT lebih diarahkan pada pembiayaan usaha mikro, kecil bawah dan bawah. Diantara usaha pembiayaan tersebut adalah Pembiayaan Mudharabah, Pembiayaan Musyarakah, Pembiayaan Murabahah, Pembiayaan Al Bai'Bithaman Ajil, Al-Qadrul Hasan

Menurut Kusuma yang dikutip oleh Djazuli dan Janwari (2002: 185) bahwa "BMT dapat didirikan dalam bentuk KSM (Kelompok Swadaya Masyarakat) atau 
Koperasi”.

Sebelum menjalankan usahanya, Kelompok Swadaya Masyarakat mesti mendapatkan sertifikat operasi dari PINBUK. Sementara PINBUK itu sendiri mesti mendapat pengakuan dari Bank Indonesia (BI) sebagai Lembaga Pengembang Swadaya Masyarakat (LPSM) yang mendukung program proyek Hubungan Bank dengan Kelompok Swadaya Masyarakat yang dikelola oleh bank Indonesia (PHBK-BI). Selain dengan badan hukum Kelompok Swadaya Masyarakat, BMT juga bisa didirikan dengan menggunakan badan hukum koperasi, baik Koperasi Serba Usaha di perkotaan, Koperasi Unit Desa di pedesaan, maupun Koperasi Pondok Pesantren di lingkungan pesantren.

Menurut Djazuli dan Janwari (2002: 187, 189, 190) bahwa dalam BMT dibedakan antara pendiri dan pengelola. Kalau pendiri adlah mereka yang merintis pembentukan BMT, sedangkan pengelola mereka yang bekerja penuh untuk BMT. Para pengelola BMT mesti memenuhi syarat-syarat berikut memiliki landasan iman dan keikhlasan dalam beribadah, memiliki semangat dan komitmen yang kuat membela kaum dhu'afa, amanah, jujur, dan berpotensi bekerja secara profesional, minimal berpendidikan D3, sebaiknya S1, berasal dari sekitar BMT itu dan bersdia untuk bertempat tinggal disekitar BMT.

Akhir-akhir ini terdapat suatu pendekatan atau teknik baru dalam perubahan organisasi. Pendekatan atau oleh sebagian ahli disebut dengan teknik manajemen tersebut dikenal dengan nama pengembangan organisasi atau organization development. Konsepsi pengembangan organisasi ini berkembang dari berbagai macam ilmu pengetahuan yang mempelajari usaha-usaha untuk mengadakan perubahan sehingga dapat lebih mampu menyesuaikan diri dengan tuntutan perubahan dan juga tuntutan masyarakat yang ingin agar organisasi dapat lebih lincah dalam memenuhi keinginan masyarakat yang selalu berubah (Indrawijaya, 1989: 37).

Pengembangan organisasi merupakan suatu perubahan berencana bukan perubahan yang tidak terkendali dan memerlukan dukungan pucuk pimpinan.

Menurut Indrawijaya (1989: 229-230) mengemukakan bahwa tujuan pengembangan organisasi ialah untuk meningkatkan efektifitas organisasi secara keseluruhan. Tujuannya adalah untuk meningkatkan keharmonisan hubungan kerja antar pimpinan dengan staf anggota organisasi, meningkatkan kemampuan memecahkan persoalan organisasi secara lebih terbuka, peningkatan keterbukaan dalam komunikasi, peningkatan semangat kerja para anggota organisasi dan juga kemampuan mengendalikan diri sendiri

Secara garis besar pengembangan organisasi dapat dibedakan atas tiga kelompok, yaitu: The Intra and Interpersonal Techniques, Integrating Individual and Organization, and Confrontation Meeting. The Intra and Interpersonal Techniques, atau teknik analisa perseorangan dan hubungan antar perseorangan.. Integrating 
Individual and Organization Technique, atau teknik pengintegrasian manusia dengan organisasi di dalamnya mencakup dua teknik pokok, yaitu job enrichment and management by objectives. Confrontation Meeting. Teknik ini merupakan teknik baru dalam pengembangan organisasi, dimana teknik ini diselenggarakan dalam rangka mengidentifikasikan kekuatan dan kelemahan yang terdapat dalam organisasi.

\section{HASIL DAN PEMBAHASAN}

\section{Rekrutmen dan Fungsi Rekrutmen}

Rekrutmen merupakan hal yang paling pokok didalam tubuh organisasi karena adanya rekrutmen dapat menambah staff atau pegawai didalam organisasi seperti BMT salah satunya adalah BMT Sanama Cileunyi Bandung. Oleh karena itu, penarikan pegawai merupakan masalah penting didalam pengadaan tenaga kerja seperti di BMT Sanama Cileunyi Bandung. Jika penarikan berhasil artinya banyak pelamar yang memasukkan lamarannya, maka peluang untuk mendapatkan tenaga kerja baru akan lebih terbuka dan akan mendapatkan sejumlah pegawai yang berkualitas. Sedangkan yang dimaksud dengan rekrutmen anggota yang ada di BMT Sanama Cileunyi Bandung adalah usaha untuk mencari dan mempengaruhi tenaga kerja, agar mau melamar lowongan pekerjaan yang ada dalam suatu organisasi. Dapat diartikan bahwa rekrutmen merupakan langkah pertama dalam menerima seseorang dalam suatu lembaga atau perusahaan (Wawancara dengan Manajer BMT Sanama Cileunyi Bandung Bapak Akhmad Gozali).

Melalui rekrutmen inilah kontak pertama kali diusahakan organisasi atau perusahan untuk pegawai potensial, melalui rekrutmen inilah banyak individu datang untuk mengenal organisasi dan yang ada pada akhirnya nanti memutuskan ingin bekerja denganya atau tidak. Suatu usaha rekrutmen yang dirancang dan dimanage dengan baik akan menghasilkan pelamar yang berkualitas baik dan sebaliknya yang terjadi apabila usaha ini dijalankan setengah-setengah. Pegawai yang berkualitas tidak dapat dipilih apabila mereka tidak mengetahui adanya lowongan pekerjaan sehingga tidak melamar. Dengan rekrut harus diusahakan bahwa orang-orang dengan kualitas tinggi mengetahui kesempatan kerja ini, perusahaan atau organisasi perlu menyediakan informasi yang cukup mengenai pekerjaan sehingga pelamar dapat memperrtimbangkan kesesuaiannya dengan minat dan kualifikasi mereka.

Pegawai merupakan sumber daya yang paling penting dalam organisasi publik. Pegawai yang baik dan memenuhi standar kualifikas, hanya akan dapat diperoleh melalui upaya rekrutmen yang efektif. Supaya dapat melakukan proses rekrutmen secara efektif, harus tersedia informasi akurat dan berkelanjutan mengenai jumlah dan kualifikasi individu yang diperlukan untuk melaksanakan berbagai tugas pokok dan fungsi dalam organisasi (Sulistiyani dan Rosidah, 2003: 
133).

Penentuan kebutuhan pegawai adalah penetapan-penetapan kuantitas dan kualitas pegawai yang harus didasarkan atas pemikiran yang rasional, dengan demikian sesuatu instansi harus mempunyai jumlah pegawai yang cukup dan berkualitas tepat sesuai dengan jenis, sifat dan volume pekerjaan yang dibebankan kepadanya berdasarkan hasil analisa jabatan.

Didalam tubuh BMT sendiri bahwa peranan anggota sebagai pegawai memiliki peranan yang cukup penting dimana teknik operasionalisasi dan dalam pengembangannya sangat bergantung pada kualitas anggota yang direkrut. Sedangkan di BMT bahwa status keanggotaan dapat digolongkan menjadi beberapa kriteria yaitu (1) Anggota Pendiri (2) Anggota Pengurus (3) Anggota Pengelola (4) Anggota Nasabah.

Sedangkan fungsi dari rekrutmen anggota yang ada di BMT Sanama Cileunyi Bandung pada dasarnya meliputi Untuk memikat para pelamar, artinya dengan adanya rekrutmen maka pihak BMT dapat memikat para pencari kerja untuk ikut melamar ke BMT Sanama, Untuk menyaring calon pelamar, kegiatan rekrutmen salah satu fungsinya yaitu untuk menyaring para pelamar supaya pihak BMT lebih mudah dalam melakukan penyeleksian, sehingga tidak sembarang orang yang dapat bekerja di BMT, Untuk menambah anggota dalam artian staff (pegawai) bagi BMT Sanama Cileunyi Bandung, dengan adanya rekrutmen maka otomatis pegawai pun akan bertambah dengan sendirinya, sehingga akan banyak pekerjaanpekerjaan yang dapat dibantu oleh anggota/kayawan baru, Untuk memperluas jaringan kerja BMT Sanama, disamping menambah anggota atau karyawan, fungsi dari rekrutmen itu yaitu memperluas jaringan kerja, karena semakin luas jaringan kerja BMT, maka akan semakin mudah pula dalam mengembangkan perusahaan, Agar bisa menambah dan menyalurkan segala jenis produk BMT Sanama, fungsi rekrutmen juga dapat menambah serta menyalurkan segala jenis produk yang ada di BMT, karena dengan adanya rekrutmen, maka karyawan-karyawan yang baru bergabung bisa ikut berpartisipasi dalam mengajukan produk baru yang harus di adakan di dalam tubuh BMT, Agar lebih mudah mensosialisasikan segala jenis produknya kepada masyarakat sekitarnya oleh para karyawan, Mensosialisasikan produk bukanlah hal yang mudah untuk dilakukan oleh setiap organisasi atau BMT, akan tetapi dengan adanya rekrutmen maka kegiatan mensosialisasikan produk akan terasa lebih mudah, karena semakin banyak karyawan yang bekerja di BMT maka akan semakin cepat pula proses sosialisasi ini tersebar ke berbagai arah, dan tentunya akan semakin cepat dalam proses perkembangan BMT (Wawancara dengan Manajer BMT Sanama Cileunyi Bandung Bapak Akhmad Gozali). 


\section{Pola Rekrutmen Anggota di BMT Sanama}

Pola rekrutmen adalah konstansi berbagai praktek rekrutmen oleh perusahaan atau organisasi. Sungguhpun pada dasarnya setiap organisasi harus berprinsip untuk terbuka bagi kelompok sosial manapun, namun pada level parktis. Kerapkali sulit dihindari bahwa tiap kecenderungan tipe perusahaan menstrukturkan perbedaan dalam menatap konsep rekrutmen yang dianggap ideal bagi perusahaannya (Erawan, et al, 2010: 17).

Pola rekrutmen dibagi menjadi dua cara. Pertama pola rekrutmen terbuka, yakni dengan menyediakan dan memberikan kesempatan yang sama bagi seluruh pelamar untuk ikut bersaing dalam proses penyeleksian. Dasar penilaian dilaksanakan melalui proses dengan syarat-syarat yang telah ditentukan melalui pertimbangan-pertimbangan yang objektif rasional. Dimana setiap pelamar yang memenuhi syarat untuk mengisi jabatan yang telah di sediakan oleh pihak perusahaan. Kedua, pola rekrutmen tertutup yaitu adanya kesempatan bagi para pelamar untuk melamar, akan tetapi dengan kualifikasi dan syarat-syarat yang telah ditentukan oleh pihak perusahaan, sehingga hanya individu-individu yang memenuhi kualifikasi dan syarat-syarat tersebut yang dapat menduduki jabatanjabatan yang tersedia di perusahaan (Tangkilisan: 2003: 188).

Pola rekrutmen anggota yang dilakukan di BMT pada dasarnya merupakan wewenang dari anggota pendiri yang berdomisili di sekitar BMT. Dan terdiri dari tiga sampai lima orang yang bertugas sebagai Ketua, Sekertaris dan Bendahara dan bertanggung jawab atas perkembangan BMT oleh karena itu perlu memeriksa BMT, memberikan pengarahan dan mengontrol segala perkembangan dari BMT.

Di BMT Sanama sendiri bahwa pola perekrutan anggota (pegawai) hampir memiliki kesamaan dengan cara perekrutan di perusahaan-perusahaan lain. pihak BMT mengadakan Analisis Job (Job Analysis) yakni kegiatan pengumpulan dan pencatatan informasi secara sistematis tentang pekerjaan dalam BMT ini. Kegiatan ini meliputi dua: (a) Job Description, dan (b) Job Spesification.

Adanya kegiatan ini dimaksudkan untuk melihat kekosongan job yang ada di BMT dan kebutuhan akan pegawai untuk ditempatkan di masing-masing job yang sudah ditetapkan.

Proses rekrutmen yang dilakukan di BMT Sanama disesuaikan dengan kebutuhan karyawan yang ada di BMT. Untuk mengisi jabatan yang sifatnya sangat vital, maka dibutuhkan kriteria calon anggota yang sangat berkualitas dan memiliki skill yang cukup tinggi. Contohnya untuk mengisi kekosongan jabatan sebagai kolektor dan super visi, maka pihak BMT Sanama membutuhkan anggota yang cukup lincah dan bisa bergerak denga cepat dia memiliki kemampuan didalam 
memasarkan produk dari BMT.

Sedangkan yang menjadi kualifikasi dari proses seleksi yang ada di BMT Sanama meliputi umur (16 tahun - 25 tahun), keahlian (bidang pemasaran dan keuangan), pendidikan (SMU, Diploma, dan S1), jenis kelamin (laki-laki dan perempuan), tampang (meyakinkan, berpenampilan rapih), karakter (mudah bersosialisasi), pengalaman kerja (sudah pernah bekerja minimal satu tahun) (Wawancara dengan Manajer BMT Sanama Cileunyi Bandung Bapak Akhmad Gozali).

Sesudah menganalisa job diatas dan kriteria calon seleksi, maka pihak BMT Sanama membuka informasi dengan menempelkan dan menyebarkan pamflet di tempat-tempat informasi seperti masjid dan lain-lain, atau menyebarkannya melalui media sosial (facebook, website, dan lain sebagainya) ataupun koran, serta mengumumkan lewat pegawai intern sendiri untuk menyebarkan informasi yang ada sesudah kegiata-kegiatan ritual (shalat).

Dapat disimpulkan dari penjelasan diatas bahwa pola rekrutmen yang dilakukan di BMT Sanama adalah pola rekrutmen tertutup, dimana pihak BMT Sanama mengadakan analisis job dan calon kriteria pelamar terlebih dahulu, kemudian melakukan penyebaran lowongan pekerjaan sebelum menerima lamaran-lamaran yang masuk, sehingga hanya pelamar-pelamar yang memenuhi kriteria-kriteria dan kualifikasi yng telah di tetapkan pihak BMT lah yang dapat mengajukan lamaran kepada pihak BMT.

Sedangkan langkah-langkah rekrutmen yang diterapkan di BMT Sanama pada dasarnya dilakukan secara bertahap yang meliputi empat tahapan atau langkah diantaranya

Langkah yang pertama, adalah bahwa pihak BMT mengadakan tes berupa tes tertulis dan tes wawancara.

Tes tulis yang digunakan berupa tes kemampuan bagi calon anggota (karyawan), dari tes ini bermaksud mengukur kemampuan yang bersifat umum, mulai dari kemampuan intelektual, bahasa dan keterampilan secara kuantitatif sampai pada kecepatan persepsi. Kemampuan kognitif (kognitive ability test) yang difokuskan pada bidang matematika, yang dinilai sebagai predikator terbaik untuk meramalkan kemampuan bekerja dan kemampuan berhitung untuk ditempatkan di bagian akuntansi.

Disamping itu, yang banyak dipergunakan didalam tes ini adalah kemampuan yang bersifat kognitif umum (general cognitive ability test) sebagaimana ujian yang dilakukan di sekolah. Pada tes ini mencakup kemampuan intelektual dan keterampilan yang bersifat kuantitatif. Asumsi dari adanya tes ini bagi pihak BMT, bahwa orang yang memiliki kemampuan integrasinya secara umum tinggi, maka orang tersebut mampu belajar secara cepat dan mengadaptasi perubahanperubahan kondisi secara cepat pula. Dengan kata lain bahwa calon anggota 
(pegawai) yang intelegensi umumnya cukup tinggi, merupakan seseorang yang mampu melaksanakan pekerjaan secara baik. Secara kriteria bahwa tes kemampuan ini meliputi, Tes intelektual, dan Tes berhitung/ tes intelegensi

Tes wawancara pada dasarnya sering digunakan dalam setiap seleksi pegawai dan dianggap perlu oleh pihak BMT Sanama, karena untuk mengukur sejauhmana kemampuan praktis pelamar dalam mengerjakan pekerjaan dan juga untuk mmperoleh gambaran apakah pelamar dapat diajak bekerja sama atau tidak.

Adapun wawancara yang dilaksanakan mengacu pada prosedur sebagai berikut, latar belakang pendidikan dan pengalaman kerja, minat dan bakat, sikap dan kebutuhan, kemampuan-kemampuan analisis dan manipulatif, keterampilan dan kemampuan teknik

Langkah yang kedua, setelah diadakannya tes maka pihak BMT Sanama melakukan penyaringan anggota dengan lima terbaik bagi peserta (calon anggota) yang dinyatakan lulus seleksi. Maka, bagi calon anggota yang lulus diberikan kesempatan untuk melakukan pelatihan (magang) kurang lebih selama tiga bulan. Ini merupakan cara yang dianggap efktif oleh BMT Sanama dan lazim dipergunakan untuk melatih calon anggota. Observasi dan partisipasi adalah perlu untuk belajar sambil bekerja. Petunjuk dan nasehat yang baik oleh seorang anggota senior (pegawai) adalah sangat berguna bagi para peserta. Saran-saran, bantuan dalam kesulitan-kesulitan, mengambil bagian dari fakta-fakta, penjelasan mengenai alasan-alasan untuk keputusan-keputusan tertentu dan pertanyaan-pertanyaan kepada peserta latihan seperti "Bagaimana saudara akan menyelesaikan masalah khusus ini?" juga merupakan bantuan. Masa magang ini merupakan masa percobaan bagi calon anggota (pegawai) yang terekrut belum ditetapkan menjadi karyawan tetap.

Adanya proses magang ini dimaksudkan untuk memberikan informasi dan sekaligus gambaran kepada calon anggota (pegawai) mengenai Job Description dan Job Specification mengenai pekerjaan yang harus dijalankan dan yang harus diisi.

Langkah ketiga, selama proses magang pihak BMT Sanama melakukan penilaian terhadap hasil dari magang. Penilaian ini dimaksudkan untuk melihat calon anggota (pegawai) apakah memiliki bukti loyalitas tinggi terhadap BMT atau tidak? Dari adanya penilaian ini diharapkan akaan terekrut calon anggota yang memiliki loyalitas tinggi. Sebab, masih ada calon anggota yang hanya iseng-iseng saja mengikuti tes ini yang kurang komitmen terhadap lembaga perekonomian seperti BMT. Dengan kata lain, untuk menghindari adanya anggota yang hanya mencari keuntungan didalam lembaga seperti BMT, bagi mereka yang memiliki keinginan dan kemauan keras untuk tetap eksis didalamnya dengan keahlian yang dia miliki, maka dinyatakan lulus.

Penilaian ini mempunyai kriteria-kriteria khusus didalamnya. Dengan melihat keahlian bagi calon anggota, apabila calon anggota memiliki kemampuan 
didalam memasarkan produk, maka dia akan ditempatkan di bagian pemasaran. Dan apabila dia memiliki kemampuan didalam berhitung maka dia akan di tempatkan di bagian akuntansi. Dari calon anggota yang dinyatakan lulus dengan kriteria seperti diatas, maka diangkat menjadi calon karyawan BMT Sanama dengan gaji masih bersifat honorer.

Langkah keempat, adalah langkah penempatan dari calon anggota (pegawai), setelah melakukan beberapa tahapan-tahapan diatas dan dinyatakan lulus, maka calon anggota diangkat menjadi anggota (pegawai) dengan status menjadi karyawan tetap.

Untuk menjadi anggota (pegawai) tetap BMT Sanama, para calon anggota membutuhkan waktu yang relative lama yaitu sekitar Sembilan bulan. Hal ini merupakan proses rekrutmen dari BMT Sanama agar menghasilkan sumber daya manusia yang berkualitas (Wawancara dengan Manajer BMT Sanama Cileunyi Bandung Bapak Akhmad Gozali).

\section{Hasil yang diperoleh dari Pola Rekrutmen Anggota di BMT Sanama Cileunyi Bandung}

Sesuai dengan pola rekrutmen yang diterapkan di BMT Sanama yaitu pola rekrutmen tertutup maka dapat di simpulkan bahwa perekrutan yang dilakukan di BMT Sanama akan sangat berpengaruh terhadap perkembangan BMT Sanama. Dengan di terapkannya pola rekrutmen yang tertutup maka pelamar-pelamar yang masuk akan sesuai dengan apa yang diharapkan oleh pihak BMT.

Pada dasarnya hasil dari rekrutmen memang harus sesuai dengan apa yang diharapkan oleh pihak BMT. Namun keberhasilan pola rekrutmen yang diterapkan di BMT Sanama tergantung pada kualitas para pelamar yang masuk pula. Jika kualitas pelamar sessuai dengan apa yang diharapkan, maka dapat dikatakan bahwa pola rekrutmen yang diterapkan di BMT berhasil. Namun adakalanya perekrutan yang kita inginkan tidak sesuai dengan apa yang terjadi. Sebagai contoh perusahaan membutuhkan teller dengan kualifikasi A, B, dan C, maka pihak BMT akan mencari teller dengan kualifikasi A, B, C pula. Kemudian bagaimana jika pelamar tidak memenuhi kualifikasi tersebut? contoh kualifikasi untuk teller (A) Pendidikan minimal D3, (B) Mempunyai keahlian dalam bidang computer, (C) Mempunyai background, sedangkan yang melamar yaitu lulusan SMK, akan tetapi pelamar mempunyai kemampuan lebih dalam bidang computer, maka pihak BMT menanyakan kembali kepada pelamar, apakah background pendidikan ini bisa dianulir dengan kemampuannya atau tidak? Jika background pendidikannya bisa d anulir oleh kemampuannya maka pihak BMT bisa menerima pelamar tersebut.

Jika dari semua data pelamar yang masuk tidak ada yang sesuai dengan 
kualifikasi yang diharapkan, maka pihak BMT akan mengadakan perekrutan ulang. Sehingga strategi perekrutanlah yang harus diubah, jika kemarin menyebarkan lowongan kerja hanya melalui media sosial, maka sekarang di coba melalui Koran, maka jangkauannya pun akan lebih luas (Wawancara dengan Manajer BMT Sanama Cileunyi Bandung Bapak Akhmad Gozali).

Perekrutan yang dilakukan di BMT Sanama merupakan salah satu cara untuk mengembangkan BMT tersebut, adapun cara lain untuk mengembangkan BMT yaitu dengan cara membuat produk yang nantinya dapat di tawarkan kepada masyarakat.

Pada dasarnya, usaha yang dijalankan oleh BMT meliputi dua jenis usaha/kegiatan, yaitu:

Kegiatan Sosial (Baitul Maal), Kegiatan Baitul Maal (kegiatan sosial) merupakan kegiatan yang mengelola penerimaan zakat, infaq, dan shadaqah sekaligus mendistribusikannya lewat pembiayaan kebajikan (Qordul Hasan) tanpa bagi hasil atau hanya kembali pokok, pembiayaan ini khusus untuk kaum dhuafa yang ingin mencari peluang usaha. Jadi pada prinsipnya BMT mendidik mereka agar tidak hanya meminta (tangan bawah) akan tetapi mereka harus bekerja keras untuk mencari penghidupan yang halal dan sewaktu-waktu mereka diharapkan menjadi seorang muzaki (tangan atas).

Pada dasarnya kegiatan social (Baitul Maal) yang dilaksanakan oleh BMT untuk menunjang pelaksanaan kegiatan bisnis (Baitul Tamwil). Karena kelompok sasaran BMT adalah pengusaha kecil bawah dan kecil yang sangat rentan dalam menghadapi tantangan hidup dan mereka belum mempunyai bekal yang cukup baik secara materi maupun moral dan keterampilan dalam memulai dan mengembangkan usahanya.

Kegiatan Bisnis (Baitul Tamwil), Kegiatan bisnis (Baitul Tamwil) merupakan kegiatan utama dan kegiatan inti BMT. Kegiatan ini bertujuan membantu pengusaha kecil bawah dan kecil dengan memberikan pembiayaan yang dipergunakan sebagai modal dalam rangka mengembangkan usahanya. Dengan kegiatan bisnis ini usaha anggota berkembang dan BMT memperoleh pendapatan sehingga kegiatan BMT tersebut dapat berkesinambungan secara mandiri.sedangkan hasil yang diperoleh dari adanya pola rekrutmen diatas bahwa pada dasarnya BMT Sanama bisa mengembangkan dari segala jenis usaha yang ada di BMT tersebut.

Menurut Terry yang di kutip oleh Moekijat (1991: 3) mengatakan bahwa:

"Formally defined, organizational development includes effort to improve 
result by getting the best from employees, individually and as members of working groups. (Menurut definisi formal, pengembangan organisasi mencakup usaha-usaha untuk meningkatkan hasil dengan memperoleh yang paling baik dari para pegawai, baik secara individual maupun anggota kelompok kerja)".

Di BMT Sanama sendiri bahwa upaya pengembangan dari BMT Baitul Sanama dilakukan melalui upaya penghimpunan dan penyaluran asset serta upaya mensosialisasikan dari produk BMT yang ada.

Upaya penghimpunan asset yang dilakukan di BMT Sanama yaitu dengan cara membuka usaha simpanan, adapun simpanan yang terdapat di BMT Sanama antara lain, Simpanan Sanama Wadiah, Simpanan Sanama Mudharabah, Simpanan Sanama Terencana, Simpanan Sanama Berjangka

Upaya Penyaluran Asset, Penyaluran asset di BMT Sanama berupa jenis pembiayaan yang merupakan pemanfaatan dana untuk usaha produktif secara efektif. Namun agar lebih efektifnya pembiayaan maka jenis pembiayaan yang digunakan harus sesuai dengan penggunaan dana pembiayaan tersebut. Usaha penyaluran asset yang dilakukan di BMT Sanama meliputi Pembiayaan Sanama Murabahah, Pembiayaan dengan konsep selisih (margin) antara harga pokok/beli dengan harga jual untuk modal kerja, pengembangan usaha, investasi, dan multi jasa lainnya dengan pembayaran secara angsuran bulanan atau mingguan. Pembiayaan mulai dari Rp. 500.000,- s/d Rp. 50.000.000,-. Pembiayaan Sanama Mudharabah, Penyertaan modal usaha dengan konsep bagi-hasil pendapatan (revenue sharing) berdasarkan komposisi modal. Pembiayaan mulai dari Rp. 5.000.000,- s/d Rp. 50.000.000,-. Pembiayaan Sanama Hiwalah, Merupakan pengalihan piutang nasabah kepada BMT (Anjak Piutang). Dimana piutang nasabah dibayarkan terlebih dahulu oleh BMT dan kemudian BMT menagih piutang tersebut kepada pihak yang berhutang kepada nasabah.

\section{Upaya Sosialisasi produk di BMT Sanama Cileunyi Bandung}

Sebagai sebuah praktik keuangan baru di masyarakat, keberadaan dan pelaksanaan BMT di Indonesia masih perlu di sosialisasikan kepada masyarakat. Sosialisasi tersebut bukan hanya bagi masyarakat umum, namun juga kalangan Lembaga Perekonomian Islam yang lainnya dan bahkan otoritas perbankan seperti Bank Indonesia.

Oleh karena itu, lambatnya proses sosialisasi dari produk BMT merupakan salah satu kendala dan ikut mempengaruhi bagi perkembangan BMT pada khususnya. Adanya proses sosialisasi produk merupakan salah satu bentuk pengembangan dari BMT yang harus dilaksanakan oleh pihak BMT sendiri.

Akan tetapi di satu sisi bahwa keberhasilan lembaga perekonomian Islam 
dalam mensosialisasikan segala produknya seperti BMT salah satunya tidak lepas dari peranan ulama. Dalam mensosialisasikan sistem perekonomian Islam kepada masyarakat, setidaknya ada empat unsur penting dalam mensosialisasikan segala produk, sebagai berikut: Pertama, menjelaskan kepada masyarakat bahwa system perekonomian (perbankan syari'ah) pada dasarnya adalah penerapan (tathbiq) fiqih mu'amalab maaliyah. Kedua, mengembalikan masyarakat pada fitrah alam dan fitrah usaha yang sebelumnya telah mengikuti syari'ah terutama dalam pertanian, perdagangan, investasi, dan perkebunan yang telah dikebiri oleh adanya system liberalisasi. Ketiga, meluruskan fitrah bisnis yang rusak seperti meluasnya ungkapan "cari duit secara haram pun susah, apalagi secara halal". Ini jelas merupakan pola pikir Yahudi yang berlandaskan ajaran Machiaveli yang menghasilkan segala cara tanpa aturan etika dan norma hukum. Keempat, membantu menyelamatkan perekonomian bangsa melalui pengembangan sosialisasi perbankan syari'ah (Syafi'I, 2001 : 237).

Adapun cara/upaya sosialisasi produk dari BMT Sanama meliputi tiga upaya sosialisasi, yaitu: Sosialisasi perorangan, Sosialisasi perorangan dilakukan dengan cara mulut ke mulut, dalam artian pengurus, pegawai atau siapapun yang terikat dengan kemajuan BMT Sanama di anjurkan untuk mensosialisasikan produk yang ada di BMT tersebut, atau bisa melalui orang-orang yang sudah menjadi anggota (nasabah) BMT Sanama.Sosialisasi kelompok, Sosialisasi kelompok ini yaitu bahwa pihak BMT melakukan sosialisasi kepada sekelompok orang yang dilakukannya melalui acara-acara ritual di tempat ibadah seperti masjid yang dilakukan setelah shalat, pengajian-pengajian dan lain sebagainya. Pihak BMT melakukan presentasi terhadap produk-produk yang terdapat di BMT Sanama itu sendiri, sehingga dapat menarik para masyarakat untuk menjadi anggota BMT Sanama.Sosialisasi melalui media sosial dan website, Sosialisasi yang terakhir yang dilakukan oleh BMT Sanama yaitu sosialisasi melalui media sosial dan website dimana pihak BMT membuat pamflet ataupun brosur untuk di sebar ke media sosial seperti facebook, instagram, dan lain sebagainya, ataupun pihak BMT membuat website yang didalamnya terdapat produk-produk yang ada di BMT sehingga ketika orang lain mengunjungi website tersebut bisa mengetahui dan ikut bergabung menjadi anggota BMT Sanama. Apalagi zaman modern seperti ini internet sudah merajalela, bahkan rumah-rumah yang berada di pinggiran kota pun sudah dapat menggunakannya, sehingga sosialisasi produk melalui media sosial dan website ini merupakan hal yang sangat perlu (Wawancara dengan Manajer BMT Sanama Cileunyi Bandung Bapak Akhmad Gozali). 


\section{PENUTUP}

Berdasarkan uraian sebelumnya, maka dari jurnal ini dapat diambil kesimpulan sebagai berikut: Yang dimaksud dengan rekrutmen anggota yang ada di BMT Sanama Cileunyi Bandung adalah usaha untuk mencari dan mempengarhi tenaga kerja, agar mau melamar lowongan pekerjaan yang ada dlam suatu organisasi. Sedangkan untuk fungsi rekrutmen yang ada di BMT Sanama Cileunyi Bandung adalah Untuk memikat para pelamar, Untuk menyaring calon pelamar, Untuk menambah anggota dalam artian staff (pegawai) bagi BMT Sanama Cileunyi Bandung, Untuk memperluas jaringan kerja BMT Sanama, Agar bisa menambah dan menyalurkan segala jenis produk BMT Sanama, Agar lebih mudah mensosialisasikan segala jenis produknya kepada masyarakat.

Pola rekrutmen yang dilakukan di BMT Sanama dilakukan dengan pola tertutup, dimana hanya pelamar-pelamar yang memenuhi kualifikasi perusahaan lah yang dapat melamar ke BMT Sanama. Adapun langkah-langkah dari pola rekrutmen yang dilakukan di BMT Sanama ini adalah Adanya proses analisis job yang dilakukan oleh pihak pengurus, Menyebarkan informasi melalui media sosial, Koran, ataupun jaringan yang ada, Penerimaan pelamar, Adanya proses seleksi, yang meliputi: Tes tertulis, berupa tes kemampuan, yang meliputi Tes intelektual, Tes Komputer, Tes Membaca Al-Qur'an. Wawancara, Adanya proses penawaran kontrak dan penempatan kerja.

Pola rekrutmen anggota yang ada di BMT Sanama Cileunyi Bandung melibatkan unsur sumber daya manusia dan unsur job/pekerjaan yang ada di dalamnya.

Dengan menggunakan pola rekrutmen yang tertutup, maka pihak BMT akan mendapatkan karyawan yang sesuai dengan apa yang di harapkan di awal, maka dapat disimpulkan bahwa pola rekrutmen yang di terapkan di BMT Sanama sangatlah berpengaruh terhadap perkembangan BMT Sanama.

Perekrutan yang dilakukan di BMT Sanama merupakan salah satu cara untuk mengembangkan BMT tersebut, adapun cara lain untuk mengembangkan BMT yaitu dengan cara membuat produk yang nantinya di tawarkan kepada masyarakat. Adapun produk-produk yang terdapat di BMT Sanama antara lain

Penghimpunan dan penyaluran dana. Penghimpunan dana yang diperoleh dari bentuk simpanan, diantaranya: Simpanan sanama wadiah, Simpanan sanama mudharabah, Simpanan sanama terencana, Simpanan sanama berjangka

Penyaluran dana yang diperoleh dari bentuk pembiayaan, diantaranya: Pembiayaan Murabahah, Pembiayaan Mudharabah, Pembiayaan Hiwalah

Upaya sosialisasi produk BMT Sanama Cileunyi Bandung meliputi: Sosialisasi produk secara perorangan, Sosialisasi produk secara kelompok, Sosialisasi produk melalui media sosial dan website 
Setelah penelitian ini dilakukan, bagi pihak BMT Sanama sendiri agar lebih ditingkatkan lagi melaksanakan rekrutmen anggota mengingat masih adanya pemegang jabatan yang bercabang. Dalam perekrutan anggota hendaklah perhatikan prosedur-prosedur yang telah ditetapkan supaya terekrutlah anggotaanggota yang berkualitas. Langkah-langkah dalam rekrutmen yang dilakukan di BMT Sanama hendaknya di tambah agar anggota yang terekrut adalah anggota yang benar-benar berkualitas. Produk-produk yang ada di BMT hendaknya di tambah agar semakin banyak masyarakat yang ingin menjadi anggota BMT. Dalam upaya sosialisasi produk yang ada di BMT hendaknya lebih di tingkatkan kembali untuk memperluas jaringan kerja dari pihak BMT Sanama itu sendiri.

\section{DAFTAR PUSTAKA}

Alsa, A. (2010). Pendekatan Kuantitatif dan Kualitatif Serta Kombinasinya dalam Penelitian Psikologi. Yogyakarta: Pustaka Pelajar.

Arifin, Z. (2000) Memahami Bank Syari'ah (Lingkup, Peluang, Tantangan, dan Prospek) Jakarta: Alvabet.

Depdikbud RI (2001). Kamus Besar Bahasa Indonesia. Jakarta: Balai Pustaka.

Djazuli, A \& Janwari, Y. (2002). Lembaga-Lembaga Perekonomian Umat (Sebuah Pengenalan), Jakarta: PT Raja Grafindo Persada.

Gomes, F.C. (2003). Manajemen Sumber Daya Manusia. Yogyakarta: Andi Offset. Handoko, T.H. (2000). Manajemen Personalia dan Sumber Daya Manusia. Yogyakarta: BPFE. . (2003). Manajemen Edisi Dua. Yogyakarta: BPFE.

Harahap, S.S. (1996). Manajemen Kontemporer. Jakarta: PT. Raja Grafindo Persada. , (2003). Manajemen Sumber Daya Manusia. Jakarta: Bumi Aksara.

Hasan,C.B. (2001). Penuntun Penyusunan Rencana Penelitian dan Penulisan Skripsi, Jakarta: PT Raja Grafindo Persada.

Hasibuan, S.P.M. (2001). Manajemen (Dasar, Pengertian, dan Masalah). Jakarta: Bumi Aksara.

Indrawijaya, A.I. (1989). Perubahan dan Pengembangan Organisasi. Bandung: Sinar Baru.

Mangkunegara, A.P. (2001), Manajemen Sumber Daya Manusia, Bandung: Rosda. Mannulang, M. (1988) Dasar-Dasar Manajemen. Medan:Ghalia Indonesia. Moekijat, (1991). Latihan dan Pengembangan Sumber Daya Manusia. Bandung: Mandar Maju.

Moekijat. (1989).Pengembangan Organisasi. Bandung: Rosda. 
Muchtarom, Z. (1996). Dasar-Dasar Manajemen Dakwah. Yogyakarta: Al-Amin dan IKFA.

Nasution, S. (2012). Metode Research. Jakarta: Bumi Aksara.

Nawawi, H. (2001). Manajemen Sumber Daya Manusia (Untuk Bisnis Yang Kompetitif), Yogyakarta: Gadjah Mada University.

Shadily, H. (1980). Ensiklopedia Indonesia. Jakarta: Ichtiar Baru van Hoeve.

Siagian, S.P. (1999). Manajemen Sumber Daya Manusia. Jakarta: Bumi Aksara. . (2002). Kiat Meningkatkan Produktivitas Kerja. Jakarta: Rineka Cipta.

Sulistiyani,A.T. \& Rosidah. (2003). Manajemen Sumber Daya Manusia. Yogyakarta: Graha Ilmu.

Tangkilisan,H.N. (2003). Kebijakan Publik yang Membumi, Yayasan Pembaruan Administrasi Publik Indonesia, Yogyakarta

Terry,G.R. \& Rue, L.W. (2001). Dasar-Dasar Manajemen. Jakarta: Bumi Aksara.

Umar, H. (1999). Riset Sumber Daya Manusia dalam Organisasi (Bussines Research Specification), Jakarta: PT. Gramedia Pustaka Utama.

Widodo, H. Firman, M.A. Hariyadi,D. Dwiyandra, R. (1999). PAS (Pedoman Akuntansi Syari'at) Panduan Praktis Operasional Baitul Maal Wa Tamwil, Bandung: Mizan. 